\title{
Integrin-Mediated Actions of Thyroid Hormone Analogues on Tumor Cell Chemosensitivity, Integrin-Growth Factor Receptor Crosstalk and Inflammatory Gene Expression
}

\author{
Aleck H. Hercbergs ${ }^{1}$, Faith B. Davis ${ }^{2,3}$, Hung-Yun Lin $^{2,3}$, Mary K. Luidens ${ }^{2,4}$, Ran Meng ${ }^{2}$, Osnat \\ Ashur-Fabian ${ }^{5}$, Shaker A. Mousa ${ }^{3}$ \& Paul J. Davis ${ }^{2,3,4}$ \\ ${ }^{1}$ Department of Radiation Oncology, Cleveland Clinic, Cleveland, OH, USA \\ ${ }^{2}$ Signal Transduction, Inc., USA \\ ${ }^{3}$ Pharmaceutical Research Institute, Albany College of Pharmacy and Health Sciences, USA \\ ${ }^{4}$ Department of Medicine, Albany Medical College, USA \\ ${ }^{5}$ Department of Human Molecular Genetics and Biochemistry, Sackler School of Medicine, Tel Aviv, Israel \\ Correspondence: Dr. Paul J. Davis, The Pharmaceutical Research Institute, Albany College of Pharmacy and \\ Health Sciences, One Discovery Drive, Rensselaer, NY 12144 USA. E-mail: pdavis.ordwayst@gmail.com
}

Received: March 7, 2012 Accepted: March 20, 2012 Online Published: May 1, 2012

doi:10.5539/cco.v1n1p32 URL: http://dx.doi.org/10.5539/cco.v1n1p32

\begin{abstract}
Tetraiodothyroacetic acid (tetrac) and its nanoparticulate formulation induce apoptosis in cancer cells, oppose angiogenesis about xenografted human tumors and block cancer cell repair of double-stranded DNA breaks. These nongenomic actions of tetrac are initiated at a tetrac-thyroid hormone receptor on plasma membrane integrin $\alpha v \beta 3$. In this review, we examine additional anti-cancer activities of tetrac formulations at $\alpha v \beta 3$ and what is known about their mechanisms. These activities include 1) reversal of cancer cell chemoresistance $(=$ induction of chemosensitization) and 2) disruption of crosstalk between $\alpha v \beta 3$ and nearby cell surface growth factor receptors. In addition, nanoparticulate tetrac 3) alters expression of differentially-regulated inflammation-relevant genes that may be important to inflammation-supported cancer. For example, the agent downregulates genes whose products mediate cytokine responses and upregulates suppressor of cytokine signaling, SOCS4. Such actions of tetrac formulations define a multi-target functional profile, although the activities of tetrac begin at a single anatomic plasma membrane receptor on integrin $\alpha v \beta 3$.
\end{abstract}

Keywords: $\alpha v \beta 3$, thyroid hormone receptor, tumor cell

\section{Introduction}

A thyroid hormone on plasma membrane integrin $\alpha v \beta 3$ initiates the actions of the hormone and certain analogues on angiogenesis (Bergh et al., 2005; Davis et al., 2009), on tumor cell proliferation (Rebbaa, 2008; Yalcin, Bharali et al., 2010; Yalcin et al., 2010; Meng et al., 2011) and on cancer cell radiosensitivity (Hercbergs et al., 2009; Hercbergs et al., 2011). These effects are initiated nongenomically, i.e., are independent of the classical nuclear receptor for thyroid hormone (TR) (Cheng et al., 2010), and may have downstream intracellular consequences that involve specific protein trafficking (Cao et al., 2009) and modulation of expression of specific genes involved in cancer cell survival pathways. Covalently bound to a biodegradable nanoparticle that is unable to access the interior of the cell, a thyroid hormone derivative, tetraiodothyroacetic acid (tetrac), acts exclusively at a receptor site on integrin $\alpha \mathrm{v} \beta 3$ (Bergh et al., 2005) to block actions of L-thyroxine $\left(\mathrm{T}_{4}\right)$ and 3, 5, 3'-triiodo-L-thyronine $\left(\mathrm{T}_{3}\right)$ on new blood vessel formation and cancer cell division (Davis, et al., 2009; Davis et al., 2011); However, nanoparticulate tetrac (nanotetrac) and, to a lesser extent, unmodified tetrac have a panel of cancer-relevant actions in the absence of $\mathrm{T}_{4}$ and $\mathrm{T}_{3}$ (Lin et al., 2011; Davis et al., 2011). These actions include modulation of tumor cell chemosensitivity (Rebbaa, A., et al., 2008), disordering of crosstalk between the integrin and nearby receptors for vascular endothelial growth factor (VEGF) (Mousa et al., 2005, 2008; Luidens et al., 2010) and epidermal growth factor (EGF) (Lin et al., 1999; Shih et al., 2004), and antagonism of components of the inflammatory process that may be important to cancer cell biology. This review is focused on these lesser known actions of thyroid hormone analogues at integrin $\alpha v \beta 3$ beyond effects on cancer cell proliferation/apoptosis and angiogenesis. 


\section{Thyroid Hormone and Cancer Cell Chemosensitivity}

A critical defense of tumor cells against chemotherapy is the ability of several well-studied plasma membrane pumps to export anti-cancer drugs taken up by the cells, thus reducing the intracellular residence time of the agents (Baumert \& Hilgeroth, 2009; Sharom, 2008). Rebbaa et al. (2008) have shown that tetrac increases the intracellular residence time of doxorubicin in chemoresistant human breast MCF-7 cells, thus restoring chemosensitivity to this agent. Because efflux pumps-e.g., P-glycoprotein (P-gp) and other multidrug resistance proteins (MRPs) (Sharom, 2011) are the basis of resistance in tumor cells to certain anti-cancer agents, it was proposed that such pump activity was in fact opposed by tetrac. The molecular basis for this chemosensitizing action of tetrac has not yet been established, but one possibility is that the known inhibitory effect of tetrac on the sodium/proton exchanger $\left(\mathrm{Na}^{+} / \mathrm{H}^{+}\right.$antiporter) (D'Arezzo et al., 2004) acidifies cancer cells, moving intracellular $\mathrm{pH}$ away from the optimum of the P-glycoprotein pump. Interference with antiporter function may also remove the contribution to protective acidic extracellular $\mathrm{pH}$ that is an attribute of solid tumors, although other factors such as hypoxia may be more important to maintaining this attribute.

Other mechanisms of chemosensitization are of course possible and tetrac may chemosensitize by more than a single process, since the actions of multiple anti-cancer agents of different structures can be restored by this thyroid hormone analogue. These other agents include etoposide, cisplatin and trichostatin A (Rebbaa et al., 2008), however, and all three relate in one way or another to P-gp. Tetrac also appears to sensitize cancer cells to cetuximab, a monoclonal antibody to the epidermal growth factor receptor (EGFR) (Lin et al., 2011) and the antibody of course does not depend upon intracellular retention for its effect. We also know that tetrac can inhibit basal rate of repair of basal double-strand DNA breaks in tumor cells, as well as DNA breaks in cancer cells induced by radiation (Hercbergs et al., 2011). There appears to be a negative correlation between double-strand breaks and P-gp expression in tumor cells (Valenzuela et al., 1995). This may be another factor in the increased intracellular retention in tetrac-treated cells of chemotherapeutic agents subject to export by this pump.

\section{Disruption by Tetrac of Crosstalk between Integrin $\alpha v \beta 3$ and Adjacent Growth Factor Receptors}

Prior to the description of the receptor for thyroid hormone and its analogues on integrin $\alpha v \beta 3$, nongenomic effects of iodothyronines initiated at the cell surface included potentiation of the action of EGF (Lin et al., 1999). Inhibition of the action of $\mathrm{T}_{4}$ was obtained with tetrac (Shih et al., 2004). Activities of a variety of vascular growth factors, such as VEGF and basic fibroblast growth factor (bFGF) and of EGF, depend upon discrete plasma membrane receptors on blood vessel cells for specific growth factors. What studies of the action of tetrac at the thyroid hormone receptor on $\alpha v \beta 3$ have revealed is affirming evidence for the existence of crosstalk between the integrin and receptors for VEGF (Somananth et al., 2009), for FGF and platelet-derived growth factor (PDGF) (Mousa, 2010: unpublished observations) and for EGF (Shih et al., 2004).

It was initially thought that the anti-angiogenic activity of tetrac formulations reflected only the ability of these agents to prevent binding of pro-angiogenic $\mathrm{T}_{4}$ or $\mathrm{T}_{3}$ to their receptor on the integrin. However, in the chick chorioallantoic membrane (CAM) model of angiogenesis, tetrac and nanotetrac block the actions of VEGF and bFGF in the absence of agonist iodothyronines $T_{4}$ and $T_{3}$ (Mousa et al., 2008). The molecular basis of this anti-angiogenic quality of tetrac has not been established, but the complexing of $\alpha v \beta 3$ with VEGFR (VEGF receptor) (Somananth et al., 2009), a receptor tyrosine kinase (Stuttfeld \& Ballmer-Hofer, 2009), is reproduced with other growth factor receptors, such as PDGFR (Borges et al., 2000), and perhaps with EGFR (Jones et al., 1997). Such complexing of the integrin with growth factor receptors may be via the cytoplasmic domains of the protein (VEGFR2) (Somananth et al., 2009) or extracellular domains (PDGFR) (Borges et al., 2000). The interactions of the receptors with the integrin primarily involve facets of the $\beta 3$ monomer. In addition, modulation by thyroid hormone of the angiogenesis-relevant crosstalk between $\alpha v \beta 3$ and nearby growth factor receptors involves mitogen-activated protein kinase (MAPK; extracellular regulated kinase 1/2, ERK1/2). Thus, the communication can involve interactions between adjacent protein domains of the integrin and growth factor receptors, as well as ERK1/2-mediated phosphorylation (Lin et al., 1999; Shih et al., 2004).

The tetrac receptor is located in the extracellular domain of $\alpha v \beta 3$ (Cody et al., 2007; Lin et al., 2011) and both of the integrin monomers $\alpha \mathrm{v}$ and $\beta 3$ contribute to the formation of the hormone/tetrac receptor site. The integrin is highly plastic, permitting changes in configurations of the cytoplasmic and extracellular domains of $\alpha v \beta 3$ in response to protein-liganding that is essential to the transduction of the liganding signal into distinctive (discrete) responses. Given the spectrum of growth factor signals-VEGF, PDGF, bFGF, EGF-disrupted by tetrac's binding to the $\alpha v \beta 3$, the tetrac receptor must have access to outside-in and inside-out transduction pathways to negate the cellular actions of these factors. Downstream (intracellular) transduction of the growth factor signals involves an 
array of kinases, some of the activities of which (see below) can be modulated by the thyroid hormone-tetrac receptor site on $\alpha \mathrm{v} \beta 3$.

Topographically, the hormone/tetrac receptor is proximal to the RGD recognition site on $\alpha v \beta 3$ (Cody et al., 2007; Lin et al., 2011). The recognition site modulates integrin interactions with specific ECM proteins (Plow et al., 2000) and can be relevant to vascular growth factor activities (Strieth et al., 2006). Crystallographic modeling reveals that the thyroid hormone/tetrac receptor site or groove is at the interface of the 'propeller' region of $\alpha \mathrm{v}$ and the B domain of $\beta 3$ ( $\beta \mathrm{B}$ ) at the head of the heterodimeric integrin (Cody, V., et al., 2007; Freindorf et al., 2012). The $\beta$ A domain is the principal ligand-binding region of $\beta 3$. The thyroid hormone receptor site has several pockets into which hormone analogues may fit and be recognized sufficiently discretely to cause transduction of the molecular signal into downstream specific kinase activities. Pharmacokinetic analysis of binding of thyroid hormone analogues to the integrin (Lin et al., 2009) and extensive crystallographic modeling (Freindorf et al., 2012) are consistent with existence of two principal hormone analogue-binding domains: the $\mathrm{S} 1$ domain binds $\mathrm{T}_{3}$ exclusively and activates Src kinase and phosphatidylinositol 3-kinase (PI 3-K) activity within the cell; $\mathrm{S} 2$ binds both $\mathrm{T}_{3}$ and $\mathrm{T}_{4}$ and transduces hormone signals via MAPK-dependent pathways (Lin et al., 2009). The $\mathrm{S} 2$ site mediates the cancer cell proliferation effects of $\mathrm{T}_{4}$ in physiological concentrations. $\mathrm{T}_{3}$ also causes tumor cell proliferation, but may do so, at least in certain cells (Meng et al., 2011), only in supraphysiologic concentrations. Tetrac is an inhibitor of $\mathrm{T}_{3}$-binding and $\mathrm{T}_{3}$-initiated actions at both $\mathrm{S} 1$ and $\mathrm{S} 2$ and of $\mathrm{T}_{4}$-binding and its activities at $\mathrm{S} 2$ (Lin et al., 2009).

When studied in several human cancer xenograft models, tetrac or nanotetrac can promptly reduce tumor-associated vascularity by 50\% (Yalcin et al., 2010; Yalcin et al., 2010; Mousa et al., 2011). This desirable effect of tetrac and nanotetrac in the setting of experimental tumor growth is enhanced by other blood vessel-relevant activities of tetrac. Acting via the plasma membrane integrin, for example, tetrac formulations can induce expression of the thrombospondin 1 (TBSP1, TSP1) gene (Glinskii et al., 2009) that is almost invariably suppressed in cancer cells. The TBSP1 protein is an endogenous anti-angiogenic protein. Further, tetrac decreases the elaboration of bFGF into the medium by endothelial cells in the CAM model (Davis et al., 2004). Such elaboration is ordinarily an autocrine support mechanism for angiogenesis.

Beyond its effect on angiogenesis, EGF is a critical growth factor for a number of types of cancers (Yotsumoto et al., 2009) and the development and clinical application of a monoclonal antibody to the EGF receptor (EGFR), cetuximab (Mendelsohn \& Baselga, 2006), relates to a family of effects of this growth factor. That tetrac formulations reduce the effectiveness of EGF via disordering crosstalk between integrin $\alpha v \beta 3$-presumably at the level of the RGD recognition site-and EGFR is an interesting and potentially useful quality of the compounds.

Although this discussion is focused on growth factor receptors inserted in the plasma membrane and adjacent to $\alpha v \beta 3$, we would point out that there is crosstalk between the thyroid hormone-tetrac receptor on $\alpha \mathrm{v} \beta 3$ and ER $\alpha$ (Meng et al., 2011) within or at the plasma membrane of human lung cancer cells that express the estrogen receptor. In such cells, $T_{4}$ may function as a growth factor by an ER $\alpha$-dependent pathway that requires phosphorylation of ER (Tang et al., 2004).

\section{Mechanisms of Anti-inflammatory Properties of Tetrac}

The inflammatory response depends upon contributions from inflammatory cells, response-modifying cytokines and blood vessel growth factors. Thyroid hormone enhances migration in vitro in a Boyden chamber of human granulocytes and tumor cells towards cue proteins, such as vitronectin (Mousa: unpublished observations); these effects are inhibited by tetrac. The hormone enhances selected biological activities of certain cytokines, including interferon- $\gamma$ (Lin et al., 1998) and interleukin-1 (IL-1) (Tarjan \& Stern, 1995; Kim et al., 1999). As noted above, $T_{4}$ and $T_{3}$ are pro-angiogenic and such activity locally supports the inflammatory response. In contrast, tetrac and nanotetrac are anti-angiogenic via multiple mechanisms.

We have more recently examined the effect of tetrac and nanotetrac on the expression of differentially-regulated genes that are relevant to inflammation (Lin et al., 2012). In these studies conducted in human breast cancer (MDA-MD-231) cells, nanotetrac significantly $(\mathrm{P}<0.05)$ suppressed expression of 5 of 6 interleukin genes examined, including $I L-6$ and $I L-1 \alpha$, but stimulated expression of $I L-11$, a factor that supports proliferation of hematopoietic stem cells and of megakaryocyte progenitor cells. This latter effect is interpreted as clinically desirable. The tetrac formulation reduced expression of several interferon response pathway genes, e.g., IRF5, but had only a minimally suppressive effect on IRF1. Interferon-regulatory factor 5 (IRF5) protein regulates macrophage contributions to inflammation and IRF1 functions as a tumor suppressor gene (Choo et al., 2006); thus, these tetrac actions have some coherence. Unmodified tetrac and nanotetrac both stimulated expression of SOCS4, the gene product of which is a suppressor of cytokine signaling. Nanotetrac also downregulated 
expression of the chemokine CX3CL1 (fractalkine). We also know that nanoparticulate tetrac decreases expression of the epidermal growth factor receptor (EGFR) gene (Glinskii et al., 2009). EGFR engages in crosstalk with other signaling pathways involved in inflammation. The concentrations of tetrac $\left(10^{-7} \mathrm{M}\right)$ and nanotetrac $\left(10^{-7} \mathrm{M}\right.$ tetrac equivalent) employed in these gene expression experiments are those previously shown to induce apoptosis in cancer cells (Lin et al., 2011). Taken together, these microarray studies indicate that nanotetrac has coherent effects on several families of genes whose products contribute to the inflammatory response. The effects are anti-inflammatory in pattern and conceptually are desirable from the standpoint of minimizing contributions of inflammation to the support or emergence of inflammation-associated cancers. The agent is also to be tested against local inflammation, for example, in the joint space, that is not cancer-associated.

A variety of cancers have inflammatory components to their genesis or maintenance (Yadav et al., 2010; Chow et al., 2012). These tumors include those of the prostate (Sfanos \& De Marzo, 2012), liver (Sun \& Karin, 2011) and esophagus (Nicholson \& Jankowski, 2011). Anti-cancer agents which also have anti-inflammation effects, such as tetrac formulations, have some attractiveness for trial against such tumors.

\section{Discussion}

The actions of tetraiodothyroacetic acid and its nanoparticulate formulation reviewed here are mediated by a receptor site on integrin $\alpha \mathrm{v} \beta 3$ that distinguishes among thyroid hormones or derivatives (Cody et al., 2007; Lin et al., 2011). This receptor is required for local effects of iodothyronines that relate to nearby polypeptide receptors, such as those for growth factors, and to ion transporters (Cheng et al., 2010; Davis et al., 2011), such as the $\mathrm{Na}^{+} / \mathrm{H}^{+}$antiporter. The receptor mediates hormone analogue effects on protein trafficking within cells, directing, for example, cytoplasmic TR to the nucleus (Cao et al., 2009). Thyroid hormone can also support internalization of $\alpha \mathrm{v} \beta 3$ and, somewhat surprisingly, nuclear uptake of the $\alpha \mathrm{v}$, but not the $\beta 3$, monomer (Lin et al., 2007). The thyroid hormone-tetrac receptor also affects very specific gene expression, as described above in this review (Sections 1 and 3).

The $\alpha v \beta 3$ protein is generously expressed on cancer cells and rapidly-dividing blood vessel cells (Hsu et al., 2007; Lu \& Wang, 2012), but is also found on nonmalignant cells and platelets (Nieswandt, B., et al., 2009). The protein and its multifold, very specific interactions with extracellular matrix proteins that generate discrete intracellular signals are substantial contributors to cancer cell survival and tumor-building. Probing cancer cells with $\alpha v \beta 3$ antibody eliminated nongenomic actions of thyroid hormone, such as that on angiogenesis (Bergh et al., 2005), and also resulted in cells which proved difficult to propagate (Lin, unpublished observations).

This review is focused on recently-described nongenomic actions of tetrac that are relevant to cancer cells, beyond what has been reported regarding actions of tetrac formulations on apoptosis and tumor-related angiogenesis (Davis et al., 2011). That tetrac can, in addition to these actions, chemosensitize cancer cells, apparently interfere with inflammatory effects that may be important to certain tumors anti-cancer effects and disrupt crosstalk between $\alpha v \beta 3$ and other cancer-relevant cell surface growth factor receptors reflects potentially useful attributes of the agent (see Figure 1). 


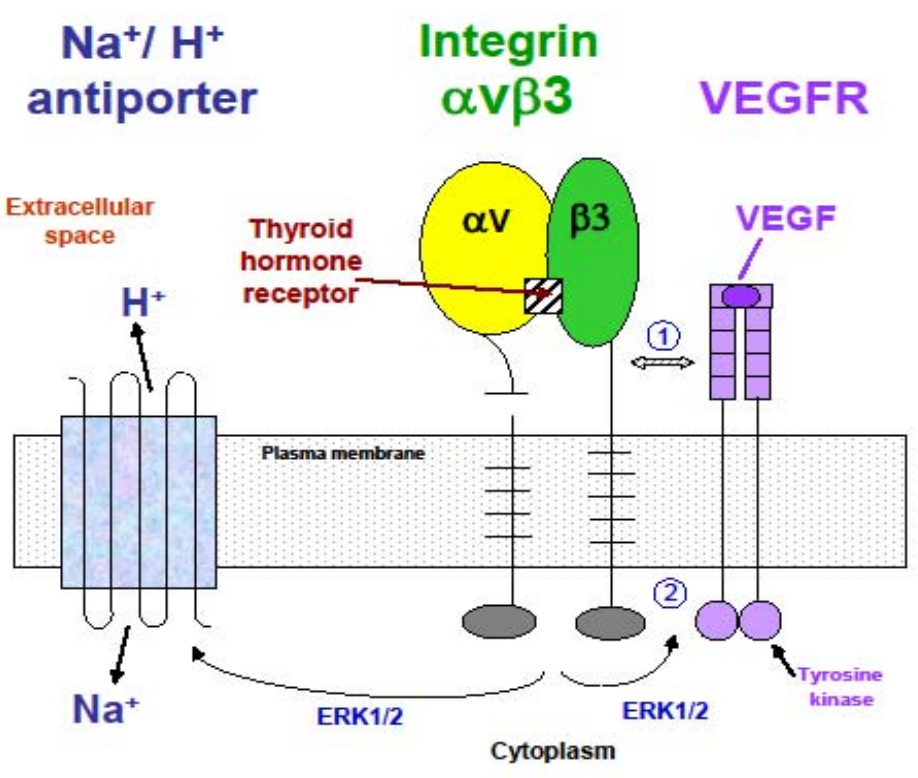

Figure 1. Schematic representation of modulation by the tetrac-thyroid hormone receptor on integrin $\alpha v \beta 3$ of activities of adjacent vascular growth factor receptors, e.g., VEGFR, and the $\mathrm{Na}^{+} / \mathrm{H}^{+}$antiporter. The heterodimeric integrin is a structural protein of the plasma membrane and bears a tetrac-thyroid hormone receptor relevant to cancer cell and dividing blood vessel cell biology (Davis et al., 2011). The $\alpha \mathrm{v}$ and $\beta 3$ monomers both contribute to formation of the hormone receptor site on the heterodimer (Cody et al., 2007; Freindorf et al., 2012). Binding of thyroid hormone analogues, including tetrac formulations, at the integrin site changes levels of activation of pools of extracellular regulated kinase 1/2 (ERK1/2) associated with the intracellular domain of the integrin ('feet'). ERK1/2 modulates activity of the $\mathrm{Na}^{+} / \mathrm{H}^{+}$antiporter (exchanger) which pumps $\mathrm{H}^{+}$out of cells in exchange for $\mathrm{Na}^{+}$(D'Arezzo et al., 2004), as shown. The authors propose that decreased activity of the exchanger in response to liganding of tetrac by $\alpha v \beta 3$ acidifies cells; this action may reduce pump activity of P-glycoprotein (P-gp) (Sharom 2011), leading to cancer cell retention of chemotherapeutic agents usually subject to export by P-gp. Also depicted are possible interactions between the integrin and adjacent vascular endothelial growth factor receptor (VEGFR). Binding of thyroid hormone analogues by the $\alpha \mathrm{v} \beta 3$ receptor modulates activity of the ligand (VEGF) at its receptor, but the model is applicable to other vascular growth factors and their specific receptors (Borges et al., 2000). Modulation of receptor activity may be accomplished by 1) interactions of the extracellular domains of the integrin and growth factor receptor or 2) by intracellular interactions of the proteins or factors the intracellular domains control. The latter may involve control of release of intracellular ERK1/2 at the cytoplasmic face of the plasma membrane. Thus, amplification (by agonist thyroid hormone, such as L-thyroxine) or suppression (by tetrac formulations) of the release of a VEGFR-relevant pool of ERK1/2 influences activity of the VEGFR. VEGFR protein is a receptor tyrosine kinase.

That formulations of tetrac have this panoply of anti-cancer actions raises the question of whether agonist thyroid hormone, e.g., $\mathrm{T}_{4}$ or $\mathrm{T}_{3}$, supports chemoresistance and the inflammatory process. In contrast to tetrac, for example, does agonist thyroid hormone enhance activity of MDR pumps? Does agonist hormone support the repair of double-strand DNA breaks in cancer cells? Silencing mediator for retinoid and thyroid hormone receptor (SMRT) may be relevant to repair of DNA breaks (Yu et al., 2006), but we do not know specifically the answers to these agonist thyroid hormone-related questions. We do know that $T_{4}$ and $T_{3}$ at physiological concentrations are pro-angiogenic (Mousa et al., 2008). $\mathrm{T}_{4}$ at such concentrations supports cancer cell division, but action of $\mathrm{T}_{3}$ on cancer cell division is at supraphysiologic levels (Meng et al., 2011). Hypothyroidism with its depressed circulating level of $\mathrm{T}_{4}$ may favorably change the clinical course of certain cancers, such as glioblastoma (Hercbergs et al., 2003) and perhaps renal cell carcinoma, when pharmacologic hypothyroidism complicates tyrosine kinase inhibitor (TKI) treatment of the tumor (Hercbergs et al., 2010; Schmidinger et al., 2011). 
Other questions relate to apparently nongenomic actions of thyroid hormone that have not yet been studied in the presence of tetrac formulations. For example, thyroid hormone enhances the respiratory burst in white blood cells (Mezosi et al., 2005), but we do not as yet know whether tetrac blocks this action. The polymerization of actin is essential to structure and mobility of cancer cells and of normal cells and is nongenomically supported by $\mathrm{T}_{4}$, but not $\mathrm{T}_{3}$ (Siegrist-Kaiser et al., 1990; Farwell et al., 2005). It is not known whether this hormonal action begins at the integrin receptor and whether tetrac opposes the effect. But S. Havaki et al. (2007) have correlated $\alpha v \beta 3$ distribution in breast cancer cells with thickness of F-actin stress fibers. This would be an interesting context in which $\mathrm{T}_{4}$ may be working in tumor cells.

\section{Acknolwedgments}

The authors gratefully acknowledge the support of M. Frank and Margaret D. Rudy that enabled some of the studies reviewed here to be carried out.

\section{References}

Baumert, C., \& Hilgeroth, A. (2009). Recent Advances in the Development of P-gp Inhibitors. Anticancer Agents Medicinal Chemistry, 9(4), 415-436.

Bergh, J. J., Lin, H. Y., Lansing, L., Mohamed, S. N., Davis, F. B., Mousa, S., \& Davis, P. J. (2005). Integrin AlphaVbeta3 Contains a Cell Surface Receptor for Thyroid Hormone that is linked to Activation of Mitogen-Activated Protein Kinase and Induction of Angiogenesis. Endocrinology, 146(7), 2864-2871. http://dx.doi.org/10.1210/en.2005-0102

Borges, E., Jan, Y., \& Ruoslahti E. (2000). Platelet-derived Growth Factor Receptor Beta and Vascular Endothelial Growth Factor Receptor 2 bind to the Beta 3 Integrin Through its Extracellular Domain. Journal of Biological Chemistry, 275(51), 39867-39873. http://dx.doi.org/10.1074/jbc.M007040200

Cao, H. J., Lin, H. Y., Luidens, M. K., Davis, F. B., \& Davis, P. J. (2009). Cytoplasm-to-Nucleus Shuttling of Thyroid Hormone Receptor-Beta1 (TRbeta1) is Directed from a Plasma Membrane Integrin Receptor by Thyroid Hormone. Endocrine Research, 34(4), 155-157.

Cheng, S. Y., Leonard, J. L., \& Davis, P .J. (2010). Molecular Aspects of Thyroid Hormone Actions. Endocrine Reviews, 31(2), 139-170. http://dx.doi.org/10.1210/er.2009-0007

Choo, A., Palladinetti, P., Passioura, T., Shen, S., Lock, R., Symonds, G., Dolnikov, A. (2006). The Role of IRF1 and IRF2 Transcription Factors in Leukemogenesis. Current Gene Therapy, 6(5), 543-550. http://dx.doi.org/10.2174/156652306778520683

Chow, M. T., Müller, A., \& Smyth, M. J. (2012). Inflammation and Immune Surveillance in Cancer. Seminars in Cancer Biology, 22(1), 23-32. http://dx.doi.org/10.1016/j.semcancer.2011.12.004

Cody, V., Davis, P. J., \& Davis, F. B. (2007). Molecular Modeling of the Thyroid Hormone Interaction with Alpha v Beta 3 Integrin. Steroids, 72(2), 165-170. http://dx.doi.org/10.1016/j.steroids.2006.11.008

D’Arezzo, S., Incerpi, S., Davis, F. B., Acconcia, F., Marino, M., Farias, R. N., \& Davis, P. J. (2004). Rapid Nongenomic Effects of 3, 5, 3'-Triiodo-L-thyronine on the Intracellular pH of L-6 Myoblasts are Mediated by Intracellular Calcium Mobilization and Kinase Pathways. Endocrinology, 145(12), 5694-5703. http://dx.doi.org/10.1210/en.2004-0890

Davis, F. B., Mousa, S. A., O’Connor, L., Mohamed, S., Lin, H.-Y., Cao, H. J., \& Davis, P. J. (2004). Pro-Angiogenic Action of Thyroid Hormone is Fibroblast Growth Factor-Dependent and is initiated at the Cell Surface. Circulation Research, 94(11), 1500-1506. http://dx.doi.org/10.1161/01.RES.0000130784.90 $237.4 \mathrm{a}$

Davis, P. J., Davis, F. B., Lin, H.-Y., Mousa, S. A., Zhou, M., \& Luidens, M. K. (2009). Translational Implications of Nongenomic Actions of Thyroid Hormone Initiated at the Integrin Receptor. American Journal of Physiology Endocrinology Metabolism, 297(6), E1238-1246. http://dx.doi.org/10.1152/ajpendo. 00480.2009

Davis, P. J., Davis, F. B., Mousa, S. A., Luidens, M. K., \& Lin, H. Y. (2011). Membrane Receptor for Thyroid Hormone: Physiologic and Pharmacologic Implications. Annual Review of Pharmacology and Toxicology, 51, 99-115. http://dx.doi.org/10.1146/annurev-pharmtox-010510-100512

Farwell, A. P., Dubord-Tomasetti, S. A., Pietrzykowski, A. Z., Stachelek, S. J., \& Leonard, J. L. (2005). Regulation of Cerebellar Neuronal Migration and Neurite Outgrowth by Thyroxine and 3, 3', 
5'-triiodothyronine. Brain Research: Developmental Brain Research, 154(1), 121-135. http://dx.doi.org/10. 1016/j.devbrainres.2004.07.016

Freindorf, M., Furlani, T., Kong, J., Cody, V., Davis, F. B., \& Davis, P. J. (2012). Combined QM/MM Study of Thyroid and Steroid Hormone Analogues Interactions with $\alpha \mathrm{v} \beta 3$ Integrin. Journal of Biomedicine and Biotechnology, in press (accepted 2 Dec 2011).

Glinskii, A. B., Glinsky, G. V., Lin, H. Y., Tang, H. Y., Sun, M., Davis, F. B., Luidens, M. K., Mousa, S. A., Hercbergs, A. H., \& Davis, P. J. (2009). Modification of Survival Pathway Gene Expression in Human Breast Cancer Cells by Tetraiodothyroacetic Acid (Tetrac). Cell Cycle, 8(21), 3554-3562. http://dx.doi.org/10.4161/cc.8.21.9963

Havaki, S., Kouloukoussa, M., Amawi K., Drosos, Y., Arvanitis, L. D., Goutas, N., ... Marinos, E. (2007). Altered expression pattern of integrin alphavbeta3 correlates with actin cytoskeleton in primary cultures of human breast cancer. Cancer Cell International, 7, 16. http://dx.doi.org/10.1186/1475-2867-7-16

Hercbergs, A., Davis, P. J., Davis, F. B., Ciesielski, M. J., \& Leith, J. T. (2009). Modification of Survival Pathway Gene Expression in Human Breast Cancer Cells by Tetraiodothyroacetic Acid (Tetrac). Cell Cycle, $8(21), 3554-3562$.

Hercbergs, A. H., Davis, P. J., Davis, F. B., Ciesielski, M. J., \& Leith, J. T. (2011). Radiosensitization and Production of DNA Double-Strand Breaks in U87MG Brain Tumor Cells Induced by Tetraiodothyroacetic Acid (Tetrac). Cell Cycle, 8(10), 352-357. http://dx.doi.org/10.4161/cc.10.2.14641

Hercbergs, A. H., Goyal, L. K., Suh, J. H., Lee, S., Reddy, S. A., Cohen, B. H., ... Barnett, G. H. (2003). Propylthiouracil-Induced Chemical Hypothyroidism with High-Dose Tamoxifen Prolongs Survival in Recurrent High Grade Glioma. Anticancer Research, 23(1B), 617-626.

Hercbergs, A. H., Ashur-Fabian, O., \& Garfield, D. (2010). Thyroid Hormones and Cancer. Clinical Studies of Hypothyroidism in Oncology. Current Opinion in Endocrinology, Diabetes and Obesity, 17(5), 432-436. http://dx.doi.org/10.1097/MED.0b013e32833d9710

Hsu, A. R., Veeravagu, A., Cai, W., Tse, V., \& Chen, X. (2007). Integrin AlphaV Beta 3 Antagonists for Antiangiogenic Cancer Treatment. Recent Patents in Anticancer Drug Discovery, 2(2), 143-158.

Jones, P. L., Crack, J., \& Rabinovitch, M. (1997). Regulation of Tenascin-C, a Vascular Smooth Muscle Cell Survival Factor That Interacts With the Alpha V Beta 3 Integrin to Promote Epidermal Growth Factor Receptor Phosphorylation and Growth. Journal of Cell Biology, 139(1), 279-293. http://dx.doi.org/10.1083/jcb.139.1.279

Kim, C. H., Kim, H. K., Shong, Y. K., Lee, K. U., \& Kim, G. S. (1999). Thyroid Hormone Stimulates Basal and Interleukin (IL)-1-Induced IL-6 Production in Human Bone Marrow Stromal Cells: a Possible Mediator of Thyroid Hormone-Induced Bone Loss. Journal of Endocrinology, 160(1), 97-102. http://dx.doi.org/10.1677/joe.0.1600097

Lin, H. Y., Martino, L. J., Wilcox, B. D., Davis, F. B., Gordinier, J. K., \& Davis, P. J. (1998). Potentiation by Thyroid Hormone of Human IFN-gamma-Induced HLA-DR Expression. Journal of Immunology, 161(2), 843-849.

Lin, H. Y., Shih, A., Davis, F. B., \& Davis, P. J. (1999). Thyroid Hormone Promotes the Phosphorylation of STAT3 and Potentiates the Action of Epidermal Growth Factor. Biochemical Journal, 338(Pt. 2), 427-432. http://dx.doi.org/10.1042/0264-6021:3380427

Lin, H. Y., Tang, H. Y., Lin, C., Sun, M., Davis, F. B., \& Davis, P. J. (2008). Thyroid Hormone Induces Nuclear Accumulation of Monomeric Integrin $\alpha \mathrm{v}$ and Formation of Integrin-Nucleoproteinj Complexes. Abstract $261,79^{\text {th }}$ Annual Meeting of the American Thyroid Association, Chicago, IL.

Lin, H. Y., Sun, M., Tang, H. Y., Lin, C., Luidens, M. K., Mousa, S. A., ... Davis, P. J. (2009). L-Thyroxine vs. 3, 5, 3'-Triiodo-L-thyronine and Cell Proliferation: Activation of Mitogen-Activated Protein Kinase and Phosphatidylinositol 3-Kinase. American Journal of Physiology Cell Physiology, 296(5), C980-C991. http://dx.doi.org/10.1152/ajpcell.00305.2008

Lin, H. Y., Landersdorfer, C. B., London, D., Meng, R., Lim, C. U., Lin, C., ... Davis, P. J. (2011). Pharmacodynamic Modeling of Anti-Cancer Activity of Tetraiodothyroacetic Acid in a Perfused Cell Culture System. PLoS Computational Biology, 7(2), e1001073. http://dx.doi.org/10.1371/journal.pcbi.100 1073 
Lin, H. Y., Cody, V., Davis, F. B., Hercbergs, A. A., Luidens, M. K., Mousa, S. A., \& Davis, P. J. (2011). Identification and Functions of the Plasma Membrane Receptor for Thyroid Hormone Analogues. Discovery Medicine, 11(59), 337-347.

Lin, H. Y., Glinsky, G. V., Glinskii, A. B., Davis, F. B., Mousa, S. A., Luidens, M. K., ... Davis, P. J. (2012). Tetraiodothyroacetic Acid (Tetrac) Acts at a Plasma Membrane Receptor to Modulate Expression of Inflammation-Related Genes in Tumor Cells. Abstract submitted to the Annual Meeting of the Endocrine Society, June, 2012.

Lu, X., \& Wang, R. F. (2012). A Concise Review of Current Radiopharmaceuticals in Tumor Angiogenesis Imaging. Current Pharmaceutical Design, 2012 (Epub ahead of print).

Luidens, M. K., Mousa, S. A., Davis, F. B., Lin, H. Y., \& Davis, P. J. (2010). Thyroid Hormone and Angiogenesis. Vascular Pharmacology, 2010(52), 142-145. http://dx.doi.org/10.1016/j.vph.2009.10.007

Mahabeleshwar, G. H., Feng, W., Phillips, D. R., \& Byzova, T. V. (2006). Integrin Signaling is Critical for Pathological Angiogenesis. Journal of Experimental Medicine, 203(11), 2495-2507. http://dx.doi.org/10.1084/jem.20060807

Mahabeleshwar, G. H., Feng, W., Reddy, K., Plow, E. F., \& Byzova, T. V. (2007). Mechanisms of Integrin-Vascular Endothelial Growth Factor Cross-Activation in Angiogenesis. Circulation Research, 101(6), 570-580. http://dx.doi.org/10.1161/CIRCRESAHA.107.155655

Mendelsohn, J., \& Baselga, J. (2006). Epidermal Growth Factor Receptor Targeting in Cancer. Seminars in Oncology, 33(4), 369-385. http://dx.doi.org/10.1053/j.seminoncol.2006.04.003

Meng, R., Tang, H. Y., Westfall, J., London, D., Cao, J. H., Mousa, S. A., ... Lin, H. Y. (2011). Crosstalk between Integrin $\alpha v \beta 3$ and Estrogen Receptor- $\alpha$ is Involved in Thyroid Hormone-Induced Proliferation in Human Lung Carcinoma Cells. PLoS One, 6(11), e27547. http://dx.doi.org/10.1371/journal.pone.0027547

Mezosi, E., Szabo, J., Nagy, E. V., Borbely, A., Varga, E., Paragh, G., \& Varga, Z. (2005). Nongenomic Effect of Thyroid Hormone on Free-Radical Production in Human Polymorphonuclear Leukocytes. Journal of Endocrinology, 185(1), 121-129. http://dx.doi.org/10.1677/joe.1.05968

Mousa, S. A., O'Connor, L. J., Bergh, J. J., Davis, F. B., Scanlan, T. S., \& Davis, P. J. (2005). The Proangiogenic Action of Thyroid Hormone Analogue GC-1 is initiated at an Integrin. Journal of Cardiovasular Pharmacology, 46(3), 356-360. http://dx.doi.org/10.1097/01.fjc.0000175438.94906.a0

Mousa, S. A., Davis, F. B., Mohamed, S., Davis, P. J., \& Feng, X. (2008). Pro-Angiogenesis Action of Thyroid Hormone and Analogs in a Three-Dimensional in Vitro Microvascular Endothelial Sprouting Model. International Angiology, 25(4), 407-413.

Mousa, S. A., Bergh, J. J., Dier, E., Rebbaa, A., O'Connor, L. J., Yalcin, M., ... Davis, P. J. (2008). Tetraiodothyroacetic Acid, a Small Molecule Integrin Ligand, Blocks Angiogenesis Induced by Vascular Endothelial Growth Factor and Basic Fibroblast Growth Factor. Angiogenesis, 11(2), 183-190. http://dx.doi.org/10.1007/s10456-007-9088-7

Mousa, S. A., Yalcin, M., Bharali, D. J., Meng, R., Tang, H. Y., Lin, H. Y., ... Davis, P. J. (2011). Tetraiodothyroacetic Acid and Its Nanoformulation Inhibit Thyroid Hormone Stimulation of Non-Small Cell Lung Cancer Cells in vitro and Its Growth in Xenografts. Lung Cancer, 76(1), 37-45.

Napione, L., Cascone, I., Mitola, S., Serini, G., \& Bussolino, F. (2007). Integrins: a Flexible Platform for Endothelial Vascular Tyrosine Kinase Receptors. Autoimmune Reviews, 7(1), 18-22. http://dx.doi.org/10.1016/j.autrev.2007.03.007

Nicholson, A., \& Jankowski, J. (2011). Acid Reflux and Oesophageal Cancer. Recent Results Cancer Research, 185, 65-82. http://dx.doi.org/10.1007/978-3-642-03503-6_4

Nieswandt, B., Varga-Szabo, D., \& Elvers, M. (2009). Integrins in Platelet Activation. Journal of Thrombosis and Haemostasis, 7(Suppl 1), 206-209. http://dx.doi.org/10.1111/j.1538-7836.2009.03370.x

Plow, E. F., Haas, T. A., Zhang, L., Loftus, J., \& Smith, J. W. (2000). Ligand Binding to Integrins. Journal of Biological Chemistry, 275(29), 21785-21788. http://dx.doi.org/10.1074/jbc.R000003200

Rebbaa, A., Chu, F., Davis, F. B., Davis, P. J., \& Mousa, S. A. (2008). Novel function of the thyroid hormone analog tetraiodothyroacetic acid: a cancer chemosensitizing and anti-cancer agent. Angiogenesis 11(3), 269-276. http://dx.doi.org/10.1007/s10456-008-9110-8 
Schmidinger, M., Vogl, U. M., Bojic, M., Lamm, W., Heinzl, H., Haitel, A., ... Zielinski, C. C. (2011). Hypothyroidism in Patients with Renal Cell Carcinoma: Blessing or Curse? Cancer, 117(3), 534-544. http://dx.doi.org/10.1002/cncr.25422

Sfanos, K. S., \& De Marzo, A. M. (2012). Prostate Cancer and Inflammation: the Evidence. Histopathology, 60(1), 199-215. http://dx.doi.org/10.111/j.1365-2559.2011.04033.x.

Sharom, F. J. (2011). The P-glycoprotein multidrug transporter. Essays in Biochemistry, 50(1), 161-178. http://dx.doi.org/10.1042/bse0500161

Shih, A., Zhang, S., Cao, H. J., Tang, H. Y., Davis, F. B., Davis, P. J., \& Lin, H. Y. (2004). Disparate Effects of Thyroid Hormone on Actions of Epidermal Growth Factor and Transforming Growth Factor-Alpha are Mediated by 3',5'-Cyclic Adenosine 5'-Monophosphate-Dependent Protein Kinase II. Endocrinology, 145(4), 1708-1717. http://dx.doi.org/10.1210/en.2003-0742

Siegrist-Kaiser, C. A., Juge-Aubry, C., Tranter, M. P., Ekenbarger, D. M., \& Leonard, J. L. (1990). Thyroxine-Dependent Modulation of Actin Polymerization in Cultured Astrocytes. A Novel, Extranuclear Action of Thyroid Hormone. Journal of Biological Chemistry, 265(9), 5296-5302.

Somanath, P. R., Malinin, N. L., \& Byzova, T. V. (2009). Cooperation between Integrin AlphavBeta3 and VEGFR2 in Angiogenesis. Angiogenesis, 12(2), 177-185. http://dx.doi.org/10.1007/s10456-009-9141-9

Stewart, M. D., \& Wong, J. (2009). Nuclear Receptor Repression: Regulatory Mechanisms and Physiological Implications. Progress in Molecular Biology and Translational Science, 87(7), 235-259. http://dx.doi.org/10.1016/S1877-1173(09)87007-5

Strieth, S., Eichhorn M. E., Sutter, A., Jonczyk, A., Berghaus, A., \& Dellian, M. (2006). Antiangiogenic Combination Tumor Therapy Blocking $\alpha v$ Integrins and VEGF-Receptor-2 Increases Therapeutic Effects in vivo. International Journal of Cancer, 119(2), 423-431. http://dx.doi.org/10.1002/ijc.21838

Stuttfeld, E., \& Ballmer-Hofer, K. (2009). Critical Review: Structure and Function of VEGF Receptors. IUBMB Life, 61(9), 915-922. http://dx.doi.org/10.1002/iub.234

Sun, B., \& Karin, M. (2011). Obesity, Inflammation, and Liver Cancer. Journal of Hepatology, 56(3), 704-713. http://dx.doi.org/10.1016/j.jhep.2011.09.020

Tang, H. Y., Lin, H. Y., Zhang, S., Davis, F. B. \& Davis, P. J. (2004). Thyroid Hormone Causes Mitogen-Activated Protein Kinase-Dependent Phosphorylation of Nuclear Estrogen Receptor. Endocrinology, 145(7), 3265-3272. http://dx.doi.org/10.1210/en.2004-0308

Tarjan, G., \& Stern, P. H. (1995). Triiodothyronine Potentiates the Stimulatory Effects of Interleukin-1 Beta on Bone Resorption and Medium Interleukin-6 Content in Fetal Rat Limb Bone Cultures. Journal of Bone and Mineral Research, 10(9), 1321-1326. http://dx.doi.org/10.1002/jbmr.5650100908

Valenzuela, M. T., Nunez, M. I., Villalobos, M., Siles, S., Olea, N., Pedraza, V., ... Ruiz de Almodovar, J. M. (1995). Relationship between Doxorubicin Cell Sensitivity, Drug-Induced DNA Double-Strand Breaks, Glutathione Content and P-Glycoprotein in Mammalian Tumor Cells. Anticancer Drugs, 6(6), 749-757. http://dx.doi.org/10.1097/00001813-199512000-00006

Yadav, V. R., Prasad, S., Sung, B., Kannappan, R., \& Aggarwal, B. B. (2010). Targeting Inflammatory Pathways by Triterpenoids for Prevention and Treatment of Cancer. Toxins, 2(10), 2428-2466. http://dx.doi.org/10.3390/toxins2102428

Yalcin, M., Bharali, D. J., Dyskin, E., Dier, E., Lansing, L., Mousa, S. S., ... Mousa, S. A. (2010). Tetraiodothyroacetic Acid and Tetraiodothyroacetic Acid Nanoparticle Effectively Inhibit the Growth of Human Follicular Thyroid Cell Carcinoma. Thyroid, 20(3), 281-286. http://dx.doi.org/10.1089/thy.2009.0249

Yalcin, M., Dyskin, E., Lansing, L., Bharali, D. J., Mousa, S. S., Bridoux, A., ... Davis, P. J., \& Mousa. S. A. (2010). Tetraiodothyroace-tic acid (Tetrac) and Nanoparticulate Tetrac Arrest Growth of Medullary Carcinoma of the Thyroid. Journal of Clinical Endocrinology and Metabolism, 95(4), 1972-1980. http://dx.doi.org/10.1210/jc.2009-1926

Yotsumoto, F., Sanui, A., Fukami, T., Shirota, K., Horiuchi, S., Tsujioka, H., ... Miyamoto, S. (2009). Efficacy of Ligand-Based Targeting for the EGF System in Cancer. Anticancer Research, 29(11), 4879-4885.

Yu, J., Palmer, C., Alenghat, T., Li, Y., Kao, G., \& Lazar, M. A. (2006). The Corepressor Silencing Mediator for Retinoid and Thyroid Hormone Receptor Facilitates Cellular Recovery from DNA Double-Strand Breaks. Cancer Research, 66(18), 9316-9322. http://dx.doi.org/10.1158/0008-5472.CAN-06-1902 